\title{
Larkspur chemistry: Toxic alkaloids in tall larkspurs
}

\author{
GARY D. MANNERS, JAMES A. PFISTER, MICHAEL H. RALPHS, KIP E. PANTER, \\ AND JOHN D. OLSEN
}

\begin{abstract}
Authors are research chemist, USDA/ARS, Western Regional Research Center, Albany, Calif. 94710; range scientist, animal scientist, and veterinary medical officer, USDA/ARS, Poisonous Plant Research Laboratory, Logan, Utah 84321 .
\end{abstract}

\begin{abstract}
Three species of tall larkspur (Delphinium barbeyi(Huth), Delphinium occidentale(Wats.)Wats, and Delphinium glaucescens) that are toxic to cattle were chemically analyzed to determine "total alkaloid" content. $D$. barbeyi and $D$. occidentale contained more "total alkaloids" than $D$. glaucescens. The "total alkaloid" content of all plant tissues in the 3 species declined as the growing season progressed. Variation in the occurrence of specific diterpenoid alkaloids was established by gas chromatographic analysis of $D$. barbeyi plant tissues at different phenological growth stages. Highest yields of specific alkaloids were found in early growth stage plant tissues. Deltaline was the most prominent diterpenoid alkaloid in $D$. barbeyi and 14-0-acetyldictyocarpine is a new diterpenoid alkaloid with high occurrence in this plant. The toxicity of specific diterpenoid alkaloids obtained from the tall larkspurs evaluated in a mouse bioassay showed methyllcaconitine to be highly toxic. Other diterpenoid alkaloids isolated from the 3 larkspurs showed much lower levels of toxicity compared to methyllycaconitine.
\end{abstract}

Key Words: Delphinium, diterpenoid alkaloids, gas chromatography, phenological distribution

Three species of tall larkspur ( $D$. barbeyi, $D$. occidentale, $D$. glaucescens) commonly infest mountain grazing ranges of the West. Each of these tall larkspurs has been established as a source of livestock poisonings on these ranges (Kingsbury 1964, Nielsen and Ralphs 1987). Toxic diterpenoid alkaloids occurring in tall larkspurs are considered to be the causative agents of livestock poisonings; however, no specific diterpenoid alkaloid has been associated with the toxicity of these plants.

Long-term interuminal infusion of extracts from $D$. barbeyi (Olsen unpublished) containing diterpenoid alkaloids indicate that the ingestion rate, rate of absorption, rate of metabolism, and rate of elimination of alkaloids are primary determinants in the toxic susceptability of cattle. The development of clinical signs and the severity of poisoning are highly alkaloid dose dependent. The nature of specific alkaloid exposure and its dose are primary factors in toxic reactions to larkspur. Cattle increase consumption of tall larkspur as the plant matures (Pfister et al. 1988a, 1988b) coincident with an observed decline in alkaloid levels in the plant (Ralphs et al. 1988). The palatability of larkspur to cattle appears to be inversely related to alkaloid levels in the plant (Pfister et al. 1990). Toxic evaluation of extracts of $D$. barbeyi, $D$. occidentale, and $D$. glaucescens in the early bud stage of growth, utilizing a rat bioassay (Olsen 1977), reveal $D$. barbeyi to be 4 times more toxic than D. glaucescens and 10 times more toxic than $D$. occidentale.

Fifteen species of larkspur have been identified as being toxic to

\footnotetext{
Manuscript accepted 28 May 1991.
}

livestock; 10 of these larkspur species have been subjected to detailed chemical examination for specific diterpenoid alkaloids (Olsen and Manners 1989). These chemical investigations have led to the characterization of more than 100 diterpenoid alkaloids, but studies directly relating specific alkaloids to observed mammalian toxicity have been limited. Methyllycaconitine is the only diterpenoid alkaloid occurring in larkspur which has been established to be toxic to cattle (Nation et al. 1982).

More information about the occurrence and distribution of the wide range of diterpenoid alkaloids present in the tall larkspurs relative to observed toxicity is necessary to effectively attack the problem of rangeland livestock poisonings attributable to larkspur. Knowledge of the chemical factors responsible for cattle poisoning and the availability of analytical methods to detect and quantify those chemical factors would provide a means to establish when it would be safe to expose livestock to tall larkspurs. The methodology could also be used to substantiate the effectiveness of mitigation procedures designed to reduce the occurrence of specific toxic alkaloids. This report represents an initial accumulation of chemical information about the tall larkspurs and toxicologial information about diterpenoid alkaloids obtained from these $\mathrm{Del}$ phinium sp. pursuant to establishing the specific livestock toxins they contain, their distribution, and abundance. Specifically we describe the occurrence and phenological distribution of diterpenoid alkaloids in 3 species of tall larkspur (D. barbeyi, D. occidentale and $D$. glaucescens) and preliminary toxicity determinations of 9 diterpenoid alkaloids obtained from $D$. barbeyi.

\section{Materials and Methods}

\section{Plant Collection and Extraction}

Tall Larkspur (Delphinium barbeyi, Delphinium occidentale, Delphinium glaucescens) plant materials were randomly collected from livestock grazing ranges of the Rocky Mountains with historical occurrences of larkspur poisoning. Plant material was air dried and ground to pass a $1-\mathrm{mm}$ screen prior to solvent extraction. The ground plant material was exhaustively extracted with $80 \%$ ethyl alcohol in a soxhlet apparatus.

\section{"Total Alkaloid" Determination}

"Total alkaloids" (TA) occurring in tall larkspurs were quantified by a gravimetric method (Manners and Ralphs 1989) based upon an analytical method utilized by Pelletier (Pelletier et al. 1981 ) in the isolation of diterpenoid alkaloids from several species of Delphinium (Fig. 1). This analytical method was applied to various plant tissues from several phenological growth stages of the larkspurs.

Isolation and Characterization of Individual Dieterpenoid Alkaloids

Fractions A and B (Fig. 1), as obtained from each of 3 tall larkspurs were subjected to various chromatographic techniques, 


\section{Ground Plant Material}

Extract (Soxhlet)

$80 \%$ EtOH

Conc. (In vacuo)

$\mathrm{CHCl}_{3}$

$10 \%$ Aq. $\mathrm{HCl}$

$\mathrm{HCI}$ Soluble

(Discard)

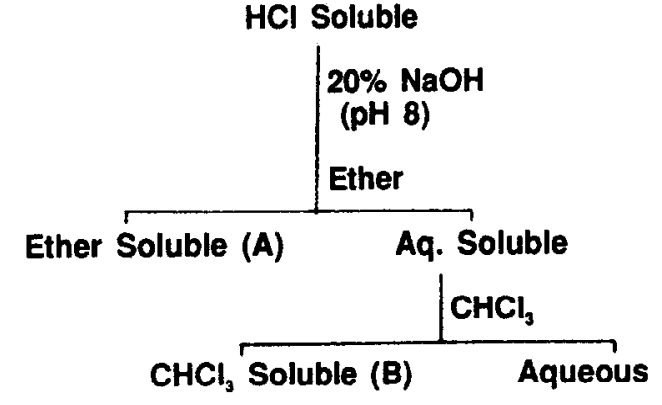

"Total Alkaloid"= A + B

Fig. 1. Extraction scheme to obtain "total alkaloid" extract.

as employed by Pelletier (Pelletier et al. 1981), to obtain 11 diterpenoid alkaloids. The identity of the individual alkaloids was determined through comparison of physical and spectral properties with those of authentic samples or prior reports.

\section{Capillary Gas Chromatographic Analysis of Diterpenoid Alkaloids}

Underivatized diterpenoid alkaloids were gas chromatographically separated and quantified according to the method of Manners and Ralphs (Manners and Ralphs 1989). Diterpenoid alkaloids used as analytical standards for external calibration of the gas chromatograph were obtained from Delphinium sp. in our laboratory or were standards kindly supplied by Dr. S. William Pelletier.

\section{Mouse Bioassay of Diterpenoid Alkaloids}

Saline solutions of individual diterpenoid alkaloids were administered to laboratory mice by subcutaneous injection between the scapula. The mice were observed for clinical signs of intoxication and the time of death was noted for determination of $\mathrm{LSD}_{50}$.

\section{Results and Discussion}

\section{Occurrence and Distribution of Diterpenoid Alkaloids in 3 Tall Larkspurs}

The "total alkaloids" measured in larkspur leaf, stem, bud, flower, and pod tissues during the bud, flower, and pod phenological growth stages is presented in Table 1 . The tabulated results reveal a higher general occurrence of "total alkaloids" in $D$. bar-
Table 2. The relative occurrence of diterpenoid alkaloids in 3 tall larkspurs.

\begin{tabular}{|c|c|c|c|}
\hline Diterpenoid alkaloid & $\begin{array}{c}D . \\
\text { occidentale }\end{array}$ & $\begin{array}{c}D . \\
\text { glaucescens }\end{array}$ & D. barbey \\
\hline $\begin{array}{l}\text { Lycoctonine type } \\
\text { Lycoctonine } \\
\text { Browniine }^{1,2,3} \\
\text { 14-Dehydrobrowniine } \\
\text { Anthranoyllycoctonine } \\
\text { Methyllycaconitine }{ }^{1,2,4} \\
\text { Delcosine }^{2,3,4} \\
\text { 14-Dehydrodelcosine } \\
\text { Glaucedine }^{2,3} \\
\text { Occidentalidine }^{3} \\
\text { Barbinene }^{4} \\
\text { 14-Deacetylnudicauline }\end{array}$ & $\begin{array}{c}+ \\
+ \\
++ \\
+ \\
- \\
+ \\
+ \\
+ \\
+ \\
- \\
-\end{array}$ & $\begin{array}{c}+++ \\
++ \\
++ \\
+ \\
+ \\
+ \\
- \\
+ \\
- \\
- \\
-\end{array}$ & $\begin{array}{l}+ \\
+ \\
+ \\
+ \\
++ \\
+ \\
- \\
- \\
- \\
+ \\
+\end{array}$ \\
\hline $\begin{array}{l}\text { 7,8, Methylenedioxy } \\
\text { Lycoctonine type } \\
\text { Deltaline } \\
\text { Dictyocarpine } \\
\text { 14-O-acetyl dictyocarpine } \\
\text { Dictyocarpinine } \\
\text { Deltamine } \\
\text { Delpheline } \\
\text { Delelatine } \\
\text { Delat } \\
\text { 6-Dehydrodeltamine' } \\
\text { 6-Acetyldelpheline } e^{3,4} \\
\text { Glaucenine }^{2,3,4} \\
\text { Glaucerine } \\
\text { Glaucephine }^{2,3,4} \\
\text { Occidentaline }^{3}\end{array}$ & $\begin{array}{c}+++ \\
++ \\
+ \\
+ \\
+ \\
+ \\
- \\
+ \\
+ \\
+ \\
+ \\
+ \\
+\end{array}$ & $\begin{array}{c}+ \\
+++ \\
- \\
- \\
- \\
- \\
- \\
- \\
- \\
+ \\
+ \\
+ \\
-\end{array}$ & $\begin{array}{l}++ \\
++ \\
++ \\
- \\
+ \\
+ \\
+ \\
+ \\
+ \\
+ \\
+ \\
- \\
+\end{array}$ \\
\hline $\begin{array}{c}\text { Hetisine Type } \\
\text { Hetisine } \\
\text { Hetisinone }^{3} \\
\text { Barbeline }^{4}\end{array}$ & $\begin{array}{l}+ \\
+ \\
-\end{array}$ & $\begin{array}{l}- \\
- \\
-\end{array}$ & + \\
\hline
\end{tabular}

'obtained and characterized in present study

2Pelletier et al. 1981

${ }^{3}$ Kulanthaivel and Pellitier 1988

4 Pelletier et al. 1989

$+=$ present, each + approx. $5 X$ Increase

-=absent

beyi and $D$. occidentale than in D. glaucescens. The "total alkaloid" content in all plant tissues of the 3 larkspurs declined as the growing season progressed.

Gas chromatography was utilized to quantify the occurrence of lycoctonine and 7,8 methylenedioxy-lycoctonine type diterpenoid alkaloids (Fig. 2) occurring in the 3 tall larkspurs. The gas chromatographic profile of diterpenoid alkaloids occurring in representative "total alkaloid" extracts of the 3 tall larkspurs is depicted in Figure 3. A comparison of the GC profiles in Figure 3 indicate inherent differences in the gross diterpenoid alkaloid composition among the 3 tall larkspurs as well as differences in the occurrence of specific diterpenoid alkaloids among the 3 species. This GC analysis of extracts of the tall larkspurs is the first successful application of a GC analytical method to measure the occurrence of specific alkaloids in any larkspur.

Table 1. Total alkaloid occurrence in 3 tall larkspurs during the growing season.

\begin{tabular}{|c|c|c|c|c|c|c|c|c|c|}
\hline \multirow[b]{2}{*}{ Species } & \multicolumn{3}{|c|}{ Stem } & \multicolumn{3}{|c|}{ Leaf } & \multicolumn{3}{|c|}{ Bud flower pod } \\
\hline & $\begin{array}{l}\text { Bud } \\
\text { stage }\end{array}$ & $\begin{array}{c}\text { Flower } \\
\text { stage }\end{array}$ & $\begin{array}{l}\text { Pod } \\
\text { stage }\end{array}$ & $\begin{array}{c}\text { Bud } \\
\text { stage }\end{array}$ & $\begin{array}{l}\text { Flower } \\
\text { stage }\end{array}$ & $\begin{array}{c}\text { Pod } \\
\text { stage }\end{array}$ & $\begin{array}{c}\text { Bud } \\
\text { stage }\end{array}$ & $\begin{array}{c}\text { Flower } \\
\text { stage }\end{array}$ & $\begin{array}{c}\text { Pod } \\
\text { stage }\end{array}$ \\
\hline $\begin{array}{l}\text { Delphinium barbeyi } \\
\text { Delphinium occidentale } \\
\text { Delphinium glaucescens }\end{array}$ & $\begin{array}{l}(\%) \\
1.031 \\
1.50 \\
0.75\end{array}$ & $\begin{array}{l}(\%) \\
0.39 \\
1.89 \\
0.39\end{array}$ & $\begin{array}{l}(\%) \\
0.13 \\
0.40 \\
0.25\end{array}$ & $\begin{array}{l}\%) \\
3.10 \\
2.43 \\
0.90\end{array}$ & $\begin{array}{l}\%) \\
1.84 \\
2.11 \\
0.60\end{array}$ & $\begin{array}{l}(\%) \\
0.23 \\
1.21 \\
0.41\end{array}$ & $\begin{array}{l}(\%) \\
1.24 \\
2.93 \\
1.76 \\
\end{array}$ & $\begin{array}{l}(\%) \\
0.87 \\
1.94 \\
1.27\end{array}$ & $\begin{array}{l}(\%) \\
1.02 \\
1.51 \\
1.28\end{array}$ \\
\hline
\end{tabular}

'Percent of dry plant material. 


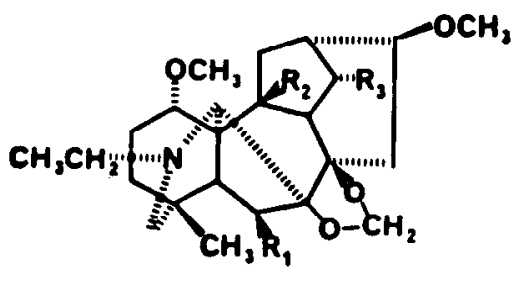

7,8 Methylenedioxy Lycoctonine type

Fig. 2. Diterpenoid alkaloid structural types.

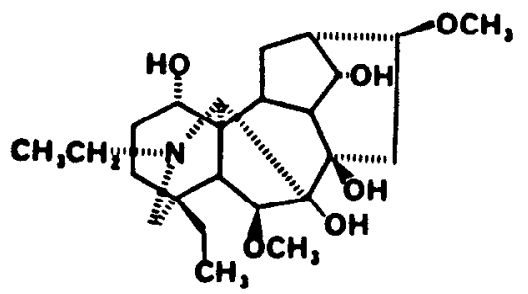

Lycoctonine Type

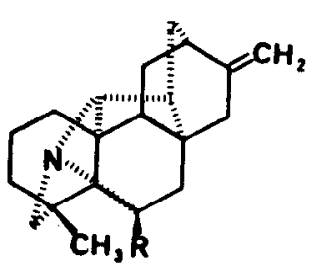

Hetisine Type
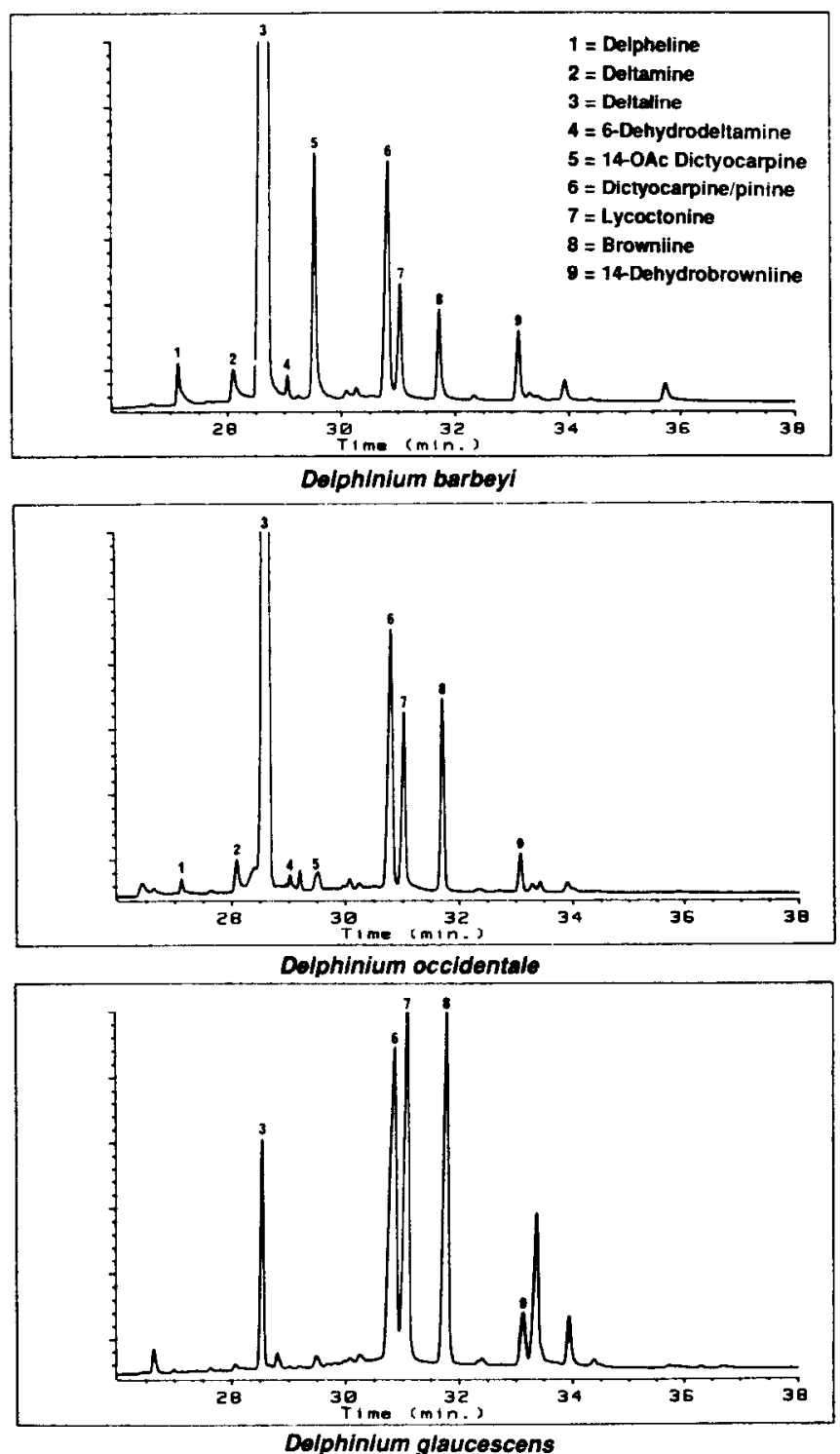

Fig. 3. Capillary gas chromatographic separation of "total alkaloids" in 3 species of tall larkspurs.

The comparative relative occurrence of the diterpenoid alkaloids occurring in $D$. barbeyi, $D$. occidentale or $D$. glaucescens is presented in Table 2. These data reveal a high occurrence of deltaline in $D$. occidentale while $D$. glaucescens is shown to contain larger amounts of lycoctonine and dictyocarpine. Deltaline, methyllycaconitine and 14-O-acetyldictyocarpine are prominent in the extracts of $D$. barbeyi. The prominence of deltaline, methyllycaconitine and 14-O-acetyldictyocarpine in $D$. barbeyi coupled with the higher observed toxicity of this tall larkspur species to rats (Olsen 1977) suggests one or more of these alkaloids may be the primary toxin(s) in this plant.

\section{Incremental Growth Season Variation of Diterpenoid Alkaloids in D. barbeyi.}

Four diterpenoid alkaloids (deltaline, 14-O-acetyldictyocarpine, dictyocarpine, and lycoctonine) occur prominently in various plant tissues of $D$. barbeyi. Analytical gas chromatography applied to extracts of these plant tissues revealed deltaline to be the most abundant diterpenoid alkaloid in all plant tissues of $D$. barbeyi, Deltaline represents $25-30 \%$ of the "total alkaloid" fraction in the leaves and stem of $D$. barbeyi during the pre-bud and bud developmental stages of the plant. Significant but lower ( $20 \%$ of TA) yields of deltaline are found in the bud, flower, and pod of $D$. barbeyi with the highest occurrence being in the flower and early pod developmental stages.

Dictyocarpine, 14-0-acetyldictyocarpine, and lycoctonine were found in much lower amounts in the various plant tissues of $D$. barbeyi. The diterpenoid alkaloid 14-O-acetyld ictyocarpine occurs consistently in all plant tissues of this tall larkspur throughout the growing season. Early season occurrences of $2-4 \%$ of TA lower to $1-2 \%$ of TA levels in the mid to late bud stage. Amounts of this alkaloid increase in excess of $4 \%$ of TA in the leaves and flowers of the plant during the flowering stage of the plant before returning to the 1-2\% of TA level at the end of the growing season.

Lycoctonine appears in significant amounts ( $>11 \%$ of TA) in the stem of $D$. barbeyi in the early developmental stages of the plant and decreases in occurrence to less than $1 \%$ by the end of the growing season. Smaller amounts $(<3 \%$ of TA) of this compound were detected in other plant tissues (leaf, bud, flower) during the growing season with little seasonal variation except for a moderate increase (4-5\% of TA) in the pod at the end of the growing season.

Dictyocarpine was found in all plant tissues of D. barbeyi. A large amount ( $4 \%$ of TA) of dictyocarpine appears in the stem of this plant in its early growth stages. Occurrence of the component decreases through the bud stage in all plant tissues. Larger amounts $(>2 \%$ of TA) appear in the flowers concurrent to the appearance of 14-0-acetyldictyocarpine before decreasing to $1 \%$ of TA or less in the pod stage of the plant. Dictyocarpine and lycoctonine occur in less than $1 \%$ of TA in the leaves of $D$. barbeyi during the entire growing cycle.

The consistant appearance of larger amounts of diterpenoid alkaloids in the early growth stages of this tall larkspur is in accord with the accumulation of toxic components and high plant toxicity during these stages. The high yield occurrence of deltaline in this plant suggests its prominence in the plant's toxicity. The esterified 
lycoctonine type diterpenoid alkaloids methyllycaconitine and anthranoyllcoctonine were degraded during GC analysis and could not be accurately quantified by this technique.

\section{Pharmacological Activity of Diterpenoid Alkaloids Occurring in Tall Larkspurs}

Nine of the diterpenoid alkaloids (deltaline, dictyocarpine, deltamine, 14-O-acetyldictyocarpine, methyllycaconitine, anthranoyllycoctonine, lycoctonine, browniine, 14-dehydrobrowniine) obtained from $D$. barbeyi in the present study have been preliminarily evaluated for toxicological activity in a mouse bioassay (Manners et al., unpublished). The results of the toxicological evaluation of the diterpene alkaloids obtained from $D$. barbeyi is summarized in Table 3. These results establish methylycoconitine as the most

Table 3. The pharmacological effects of diterpenoid alkaloids in $\mathbf{3}$ tall larkspurs.

\begin{tabular}{lccc}
\hline \hline & $\begin{array}{c}\text { Range of } \\
\text { occurrence }\end{array}$ & & $\begin{array}{c}\text { Relative } \\
\text { toxicity }\end{array}$ \\
\cline { 2 - 2 } Diterpenoid alkaloid & $D$. barbeyi & & Mouse \\
\hline Deltaline & $(\%)^{1}$ & \\
Dictyocarpine & $10.0-33.0$ & & $(22)$ \\
14-OAcDictyocarpine & $2.0-4.0$ & & $(60)$ \\
Deltamine & $1.0-4.0$ & & $(20)$ \\
Anthranoyllcoctonine & $0.0-1.0$ & & $(25)$ \\
Lycoctonine & - & $(8)$ \\
Browniine & $0.3-11.2$ & & $(13)$ \\
14-Dehydrobrowniine & $1.0-6.1$ & & $(23)$ \\
Methyllycaconitine & $1.6-7.1$ & & $(9)$ \\
\hline
\end{tabular}

'Percentage of "total alkaloid" fraction, GC analysis

${ }_{2}^{2}$ Toxicity relative to methyllycaconitine; values in parentheses = times less toxic

toxic diterpenoid alkaloid occurring in $D$. barbeyi as determined by the mouse bioassay. The other alkaloids obtained from $D$. barbeyi show toxicity to mice from 8 to $\mathbf{3 0}$ times less than that observed for methyllycaconitinine.

Only 6 of the 27 diterpenoid alkaloids (methyllycaconitine, anthranyllycoctonine, lycoctonine, deltaline, browniine and delcosine) reported in the tall larkspurs (Kulanthaivel and Pelletier 1988, Pelletier et al. 1981, Pelletier et al. 1989) (Table 2) have been previously subjected to toxicologically evaluation (Olsen and Manners 1989). Among these 6 alkaloids, only methyllycaconitine was shown to be toxic to cattle (Nation et al. 1982). Considerably lower mammalian toxicity is reported for the other 5 alkaloids. Three of these alkaloids (deltamine, dictyocarpine, and 14-0acetyldictyocarpine) tested in the mouse bioassay of this study have not been previously tested. The observed toxicity of methyllycaconitine in mice is in accord with the toxicological observations of Nations (Nation et al. 1982) for this alkaloid in cattle.

\section{Conclusion}

The tall larkspurs examined in this investigation contain large amounts of diterpenoid alkaloids ( $<2 \%$ dry plant wt.) which occur in highest yield in the bud stage of the plant development. Eight 7,8 methylenedioxylycoctonine type diterpenoid alkaloids (deltaline, 14-O-acetyldictyocarine, dictyocarpine, delpheline, deltamine, 6dehydrodeltamine, browniine, 14-dehydrobrowniine) and 3 lycoctonine type diterpenoid alkaloids (lycoctonine, methyllycaconitine, anthranoyllycoctonine) have been isolated and characterized from the "total alkaloid" extracts of 3 tall larkspurs (D. barbeyi, $D$. occidentale, $D$. glaucencens). Gas chromatographic analysis of "total alkaloid" extracts can accurately quantify the occurrence of the 7,8 methylenedioxylycoctonine type diterpenoid alkaloids and lycoctonine in the plant tissues of these larkspurs through all growth stages. The gas chromatographic technique, however, was not effective in quantifying the anthranilic acid esterified lycocto- nine diterpenoid alkaloids (methyllycaconitine, anthranoyllycoctonine) in these larkspurs.

The high occurrence of deltaline ( $>0.6 \%$ of dry plant wt.) in $D$. barbeyi and $D$. occidentale suggests that it may play a prominent role in livestock poisoning. However, preliminary mouse bioassay toxicological evaluation confirm a low mammallian toxicity for deltaline. This bioassay also establishes a low mammalian toxicity for dictyocarpine, 14-0-acetyldictyocarpine, and deltamine. A mouse bioassay toxicological evaluation of methyllycaconitine established methyllycaconitine as the most toxic diterpenoid alkaloids among those isolated from the 3 tall larkspurs.

In light of data previously reported for toxicological evaluation of methyllycaconitine in cattle, the mouse bioassy toxicological results for methyllycaconitine in this study support this alkaloid as a primary toxin in the tall larkspurs. However, dose rate response studies of tall larkspur alkaloid extracts and pure samples of methyllycaconitine must be conducted to eliminate the participation of other diterpenoid alkaloids in the toxic mechanism either individually or synergystically. While the gas chromatographic analysis utilized in this study can not be applied to the accurate detection of methyllycaconitine, it could become an important tool in the event of the synergystic participation of any 7,8 methylenedioxy-lycoctonine type diterpenoid alkaloid which occurs in the tall larkspurs. The technique could also prove a swift and valuable tool in analyzing the selective distribution of minor diterpenoid alkaloids occurring in the tall larkspurs (e.g., occidentalidine, barbinene, glaucephine, and barbeline) relative to the chemical taxonomic differentiation of toxic hybrid tall larkspur species.

If methyllycaconitine is established as the sole toxic alkaloid in the tall larkspurs, development of a swift, simple analytical methods which will measure methyllycaconitine content in tall larkspurs in the field offers the greatest hope to the livestock owner for the reduction or elimination of larkspur poisoning. Field analysis of toxic content of larkspur plants would allow on-site range management practices to prevent livestock exposure to these toxic plants based upon specific current toxin levels.

\section{References}

Kingsbury, J.M. 1964. Poisonous plants of the United States and Canada. Prentice-Hall, Englewood Cliffs, N.J, 1964. p. 131.

Kulanthaivel, $P$., and S. William Pellitier. 1988. Three new $C_{19}$-diterpenoid alkaloids from Delhinium occidentale S. Wats. Heterocycles. 27:339-342.

Manners, G.D., and M.H. Ralphs. 1989. Capillary gas chromatography of Delphinium diterpenoid alkaloids. J. Chromatography 446:427-432.

Nation, P.N., M.H. Benn, S.H. Roth, and J.K. Wilkens. 1982. Clinical signs and studies of the site of action of purified larkspur alkaloid, methyllycaconitine, administered parenterally to calves. Can. Vet. J. 23:264-266.

Nielsen, D.B., and M.H. Ralphs. 1987. Larkspur: economic consideration. pp. 119-130. In: L.F. James, M.H. Ralphs, and D.B. Nielsen (eds.), The ecology and economic impact of poisonous plants on livestock production. Westview Press, Boulder, Colo.

Olsen, J.D. 1977. Toxicity of extracts from three larkspur species (Delphinium barbeyi, $D$. glaucescens, $D$. occidentale) measured by rat bioassay. J. Range Manage. 30:237-238.

Olsen, J.D. 1978. Tall larkspur poisoning in cattle and sheep. J. Amer. Vet. Med. Assoc., 173:762-764.

Olsen, J.D., and G.D. Manners. 1989. Toxicology of diterpenoid alkaloids in rangeland larkspur (Delphinium sp.). p 291-326. In: P.R. Cheeke (ed.), Toxicants of plant origin, Vol. 1, Alkaloids. CRC Press, Baca Raton, Fla.

Pelletier, S.w., O.D. Dailey Jr., N.V. Moody, and J.D. Olsen. 1981. Isolation and structure elucidation of alkaloids of Delphinium glaucescens Rybd. J. Org. Chem. 46:3284-3293.

Pelletier, S.W., P. Kulanthaivel, and J.D. Olsen. 1989. Alkaloids of Delphinium barbeyi. Phytochem. 28:1521-1525.

Prister, J.A., G.D. Manners, M.H. Ralphs, Z.X. Hong, and M.A. Lane. 1988a. Effects of phenology, site and rumen fill on tall larkspur consumption by cattle. J. Range Manage. 41:509-514. 
Pfister, J.A., M.H. Ralphs, and G.D. Manners. 1988b. Cattle grazing tall larkspur on Utah mountain rangeland. J. Range Manage. 41:118-122. Prister, J.A., F.D. Provenza, and G.D. Manners. 1990. Ingestion of tall larkspur by cattle: separating effects of flavor from post ingestive conseanimal interactions in larkspur poisoning in cattle. J. Anim. Sci. quences. J. Chem. Ecol. 16:1697-1705. 